\section{LYSIMETERS WITHOUT EDGE FLOW: AN IMPROVED DESIGN AND SAMPLING PROCEDURE}

\author{
K. C. Cameron, * N. P. Smith, C. D. A. Mclay, \\ P. M. Fraser, R. J. McPherson, D. F. Harrison, \\ AND P. HARBotTLE
}

\begin{abstract}
A description is given of a modified lysimeter design and sampling procedure designed to prevent edge flow from occuring in large soil monolith lysimeters. An internal cutting ring at the base of the lysimeter casing produced a small annular gap between the soil monolith and the wall of the casing. This gap was filled with liquefied petrolatum, which provided a water-tight seal around the edge of the lysimeter. Water and solutes were unable to leak between the monolith and casing. The use of petrolatum as a sealant is suitable for waterflux and nutrient-leaching studies, but is not suitable for pesticide studies.
\end{abstract}

$\mathrm{L}^{2}$ YSIMETERS have been used since the mid-19th Century in a wide variety of soil and environmental research programs (Howell et al., 1991). The word lysimeter is derived from the Greek lysis, meaning dissolution or movement, and metron, to measure. Lysimeters have thus been used to collect and measure the amount (and composition) of drainage water from a defined volume of soil. Weighing lysimeters have also been used to make direct measurements of evapotranspiration. Early lysimeter studies at Rothamsted Experimental Station in England were used to study the amount and composition of drainage through unmanured and uncropped land (Miller, 1906). During the late $1930 \mathrm{~s}$, lysimeters were constructed at Coshocton, $\mathrm{OH}$, and were originally used to investigate the basic laws relating to agricultural hydrology (Harrold and Dreibelbis, 1958, 1967). Other studies have examined the leaching loss of $\mathrm{N}$ from fertilizer applied at different rates to soil under a variety of soil conditions (Morgan et al., 1942) or under different crops (Pfaff, 1963). Recently, lysimeters have been used in labeled $\left({ }^{15} \mathrm{~N}\right)$ nutrient balance studies (Chichester and Smith, 1978; Dowdell and Webster, 1980; Barraclough et al., 1984). Indeed, guidelines for waste disposal and fertilizer use appear to be increasingly dependent on results obtained from lysimeter studies designed to assess the risk of groundwater contamination. Lysimeter studies must therefore be accurate and should involve a minimum risk of error.

Early lysimeters were constructed by undermining an area of soil and inserting perforated iron plates to support the soil. Trenches were then dug around the soil block to enable walls to be constructed in order to isolate the soil monolith. Drainage water that passed through the base plate was collected and analyzed. These early lysimeters were difficult to produce and were restricted to in situ measurements across a limited range of soils generally available at a single lo-

Department of Soil Science, Lincoln Univ., Canterbury, New Zealand. Received 7 Oct. 1991. *Corresponding author.

Published in Soil Sci. Soc. Am. J. 56:1625-1628 (1992). cation. These limitations led to other designs of lysimeters being adopted in which the soil to be studied was refilled into tanks. This procedure was easier than excavating a monolith and allowed a range of soils to be studied at one location. However, refilled lysimeters have been criticized due to the artifical nature of the system and the alteration of many of the natural soil conditions, including the pathways for water and solute flow (Cassel et al., 1974). Recent advances in lysimeter design and sampling procedures have enabled large undisturbed soil monoliths to be collected and returned to a central laboratory in order to conduct experiments under controlled conditions (Belford, 1979; Brown et al., 1985; Persson and Bergstrom, 1991). Although these undisturbed-monolith lysimeters retain the natural structure and pore system present in the field soil, some uncertainty still exists about the possible influence of edge flow of water and solutes between the monolith and the lysimeter wall (Till and McCabe, 1976; Wild and Cameron, 1980; Cameron et al., 1990; Persson and Bergstrom, 1991).

The objective of this work was to improve the design and sampling procedure of large undistrubedmonolith lysimeters to prevent edge flow.

\section{Materials and Methods}

Lysimeter casings were manufactured from steel plate (5 mm thick), rolled and welded to produce a cylinder 1200 $\mathrm{mm}$ high by $800 \mathrm{~mm}$ in diameter. An internal cutting ring was also manufactured from steel plate $(5 \mathrm{~mm}$ thick by 100 $\mathrm{mm}$ high) and rolled and welded to fit inside one end of the lysimeter cylinder (Fig. 1). A small section $(10 \mathrm{~mm}$ ) of cutting ring was left protruding from the lower edge of the cylinder. The edge of the lysimeter casing was bevelled to a $45^{\circ}$ angle using an angle grinder.

Soil monoliths were collected from two different soil types: (i) Wakanui silt loam (Ustochrept) (six lysimeters), which is poorly drained with approximately $30 \mathrm{~cm}$ of silt

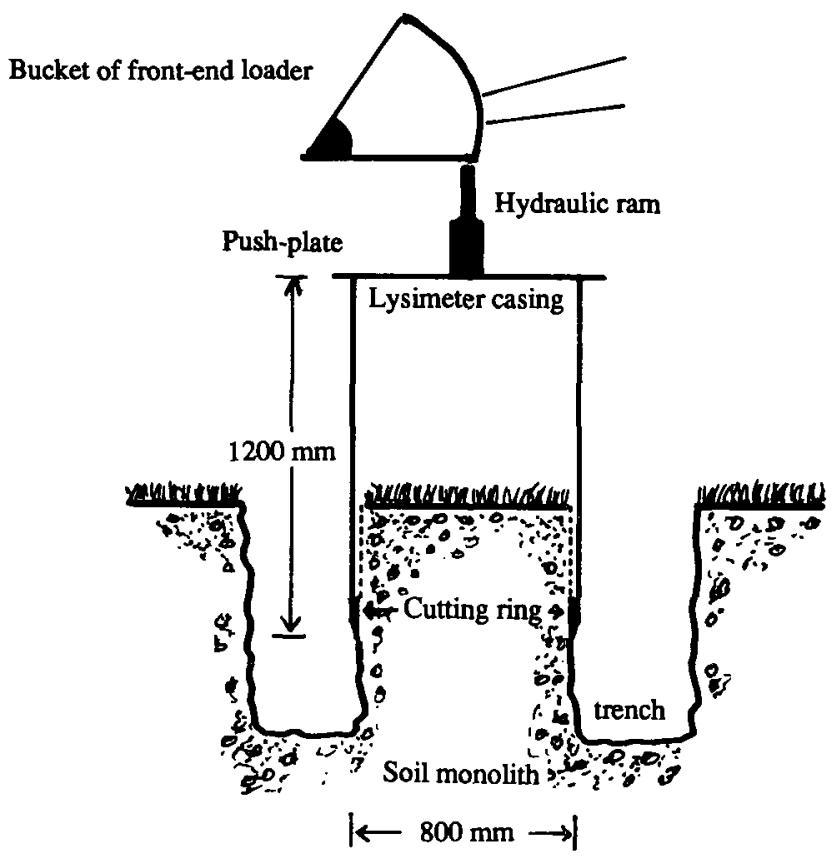

Fig. 1. Lysimeter casing showing internal cutting ring and sampling procedure. 


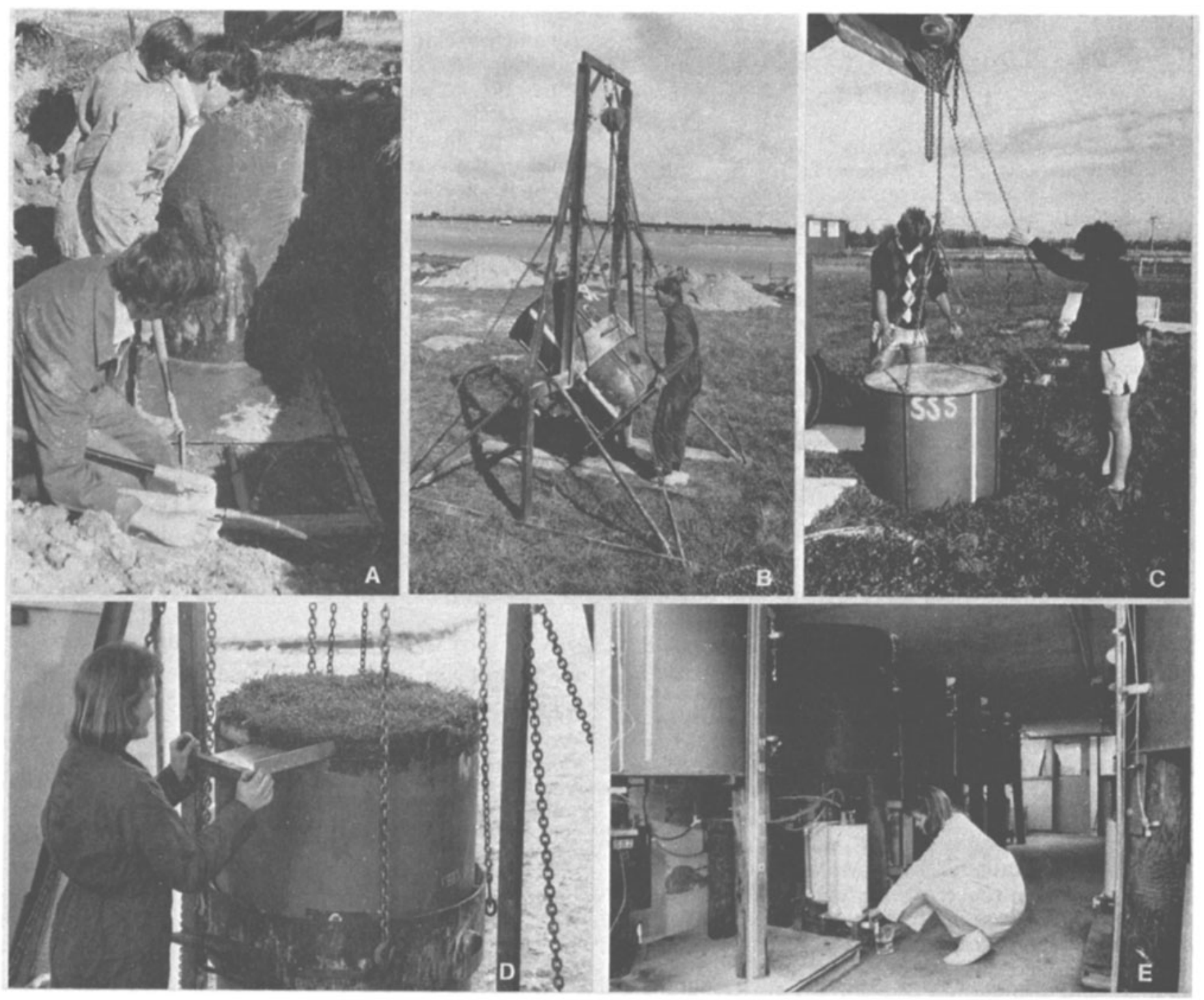

Fig. 2. Lysimeter installation and sampling procedure: (A) the cutting plate is used to detach the monolith from the underlying soil; (B) the lysimeter is gently inverted to install a tension drainage system; (C) the lysimeter is lowered through the roof of the underground laboratory; $(D)$ in the laboratory, leachate is collected from drainage vessels for subsequent analysis; (E) at the end of the experiment, the soil in the lysimeter can be sampled, by simply sliding the outer casing off the monolith, in controlled-depth increments.

loam above a clay loam subsoil, and (ii) Templeton silt loam (Udic Ustochrept) (twelve lysimeters), which has approximately $30 \mathrm{~cm}$ of silt loam above a sandy loam and sand-layered subsoil (Kear et al., 1967). Each lysimeter sampling area within each field site was spray irrigated and allowed to drain to field capacity (as measured by tensiometers). A small, hydraulically operated digger was then used to excavate a trench (500 mm wide by $1200 \mathrm{~mm}$ deep) along one side of the sampling area in order to assist with sampling. The lysimeter casing was placed on the soil surface and an annular trench (200 $\mathrm{mm}$ deep) was then dug around the lysimeter casing. The lysimeter casing was pushed over the exposed monolith directly below the cutting edge (Fig. 1) and the procedure repeated until the lysimeter casing was almost completely filled (Belford, 1979).

The top plate was removed and the annular gap between the monolith and the casing, which had been created by the internal cutting ring, was packed with 1100 -mm lengths of flat steel ( $25-\mathrm{mm}$ width by $5-\mathrm{mm}$ thickness). These packing rods were used to secure the soil monolith within the casing in order to avoid damage during transportation. Any remaining headspace between the top of the monlith and the position of the top plate was packed with a layer of sand placed on a polythene sheet over the soil surface. The top plate was then replaced.

A steel frame was constructed around the base of the lysimeter in order to push a cutting plate under the lysimeter and so detach it from the underlying soil (Fig. 2A). The frame was manufactured from two sections of channel steel ( 38 by 76 by $2400 \mathrm{~mm}$ ) bolted to two end sections of box steel ( 75 by 50 by $880 \mathrm{~mm}$ ). A shaped wooden block was used as a spacer between the frame and the lysimeter casing. A steel cutting plate ( 850 by 850 by $7 \mathrm{~mm}$ ) with a sharpened cutting edge was then pushed under the lysimeter, using the hydraulic ram. If necessary, water was sprayed onto the cutting plate to lubricate its passage beneath the soil monolith. Once the cutting plate was in position below the base of the lysimeter, the reaction frame was dismantled. The soil monolith and lysimeter casing were clamped between the top plate and cutting plate using 
four steel lifting rods ( $25-\mathrm{mm}$ diameter by $1205 \mathrm{~mm}$ ), which were inserted through holes in the top plate and the cutting plate. The lifting rods were held in position with nuts on their threaded ends. Lifting hooks and chains were attached to rings on the top ends of the lifting rods and the whole assembly carefully lifted from the trench using a front-end loader.

A tension drainage system was installed in each lysimeter to ensure that realistic field conditions were maintained at the base. To do this, the lysimeter was gently inverted on a specially constructed lifting frame (Fig. 2B). The frame was prefabricated and assembled on site, thus allowing it to be transported easily to different locations.

A large circular steel clamp $(800-\mathrm{mm}$ i.d. by $250 \mathrm{~mm}$ high) was secured around the center of the lysimeter (Fig. 2B). The metal clamp had two externally mounted stub axles $(70-\mathrm{mm}$ diam. by $45 \mathrm{~mm})$ that protruded from diametrically opposite sides. The lysimeter and clamp assembly was lifted using a 1.5-t chain hoist attached to the top of the lifting frame. The stub axles on the clamp were attached to the frame and the lysimeter gently inverted.

The base plate was removed and a 100-mm depth of subsoil was carefully removed. The base of the Wakanui soil was then peeled with a cellulose acetate-acetone mixture $(20 \% \mathrm{w} / \mathrm{v})$. The mixture was applied liberally to the base and allowed to harden. When the hardened mixture was removed from the base, a thin layer of soil was removed (1-2 mm), which opened up any soil pores blocked during the excavation (Cameron et al., 1990). This was unnecessary in the Templeton soil due to the sandy nature of the subsoil.

A hollow copper tube (5-mm o.d.) with holes (2-mm i.d.) drilled at $50-\mathrm{mm}$ spacings along its length $(2500 \mathrm{~mm})$ was positioned in a zig-zag pattern across the base. The copper tube had a fine nylon mesh (0.2-mm mesh) wrapped around it to prevent possible blockage of the drainage holes.

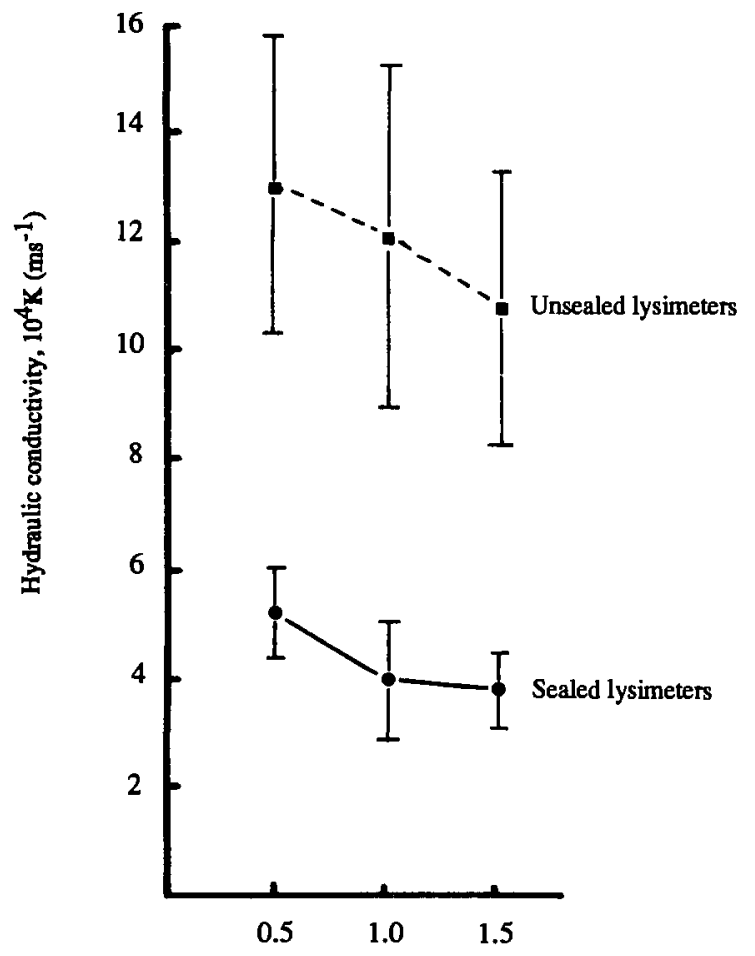

Cumulative drainage (pore volumes)

Fig. 3. Measured hydraulic-conductivity rates in sealed and unsealed lysimeters. Each point represents a mean of 10 replicate lysimeters. Bars represent standard errors. (Adapted from Cameron et al., 1990.)
This tube was designed to act as part of a fast-drainage collection system. A slow-drainage system was installed by packing fine $(<70 \mu \mathrm{m})$ silica sand (Snowsil 75, Mintech Minerals N.Z. Ltd, Christchurch, New Zealand) into the base of the lysimeter, around two hollow porous plastic tubes (20- $\mu \mathrm{m}$ pore diameter) attached to a stainless steel $\mathrm{T}$ pipe in the center of the base. Both the fast- and slowdrainage pipes were then fed through holes in a permanent drainage table base. The new base was attached using the lifting rods in a similar manner as the cutting plate. The lysimeter assembly was reinverted as described above.

The lysimeter assembly was lowered directly onto the deck of a specially constructed dual-axle trailer and bolted into position. The trailer was designed with enhanced air suspension in order to dampen the effects of road shock, which could otherwise have caused damage to the soil monolith.

Once the lysimeter had been unloaded at the laboratory site, holes (25-mm diam.) were drilled through the casing at selected depths. A screw auger was then used to extend the holes into the central region of the soil monolith. Instruments were inserted into these holes (tensiometers, gas samplers, thermistors).

Each lysimeter was then lowered into place in the laboratory until its surface was level with that of the soil at ground level (Fig. 2C) and supported by three legs. When the lysimeter was secure, the top plate was removed. The drainage base plate was sealed to the casing by applying a thin layer $(<10 \mathrm{~mm})$ of silicon sealant (Siliflex, New Zealand Expandite Ltd, Christchurch, New Zealand), which was later covered with a layer of adhesive (Araldite K2002 5-min rapid-set adhesive paste, Ciba Geigy 2000 Range Adhesives, Ciba Geigy, Christchurch, New Zealand).

The packing rods between the soil monolith and the lysimeter casing were removed. The annular gap around each monolith was inspected and found to have remained undisturbed.

Thirty liters of petrolatum (Snow White Petrolatum, Shell Chemicals, Christchurch, New Zealand) was liquified by heating it (approximately $50^{\circ} \mathrm{C}$ ) in a drum placed on a hot plate. A grease-gun filler pump was used to pump the liquified petrolatum through a small copper coil $(150-\mathrm{mm}$ diam.), which was heated by a gas burner and connected to a 1100-mm length of straight copper tube (3-mm o.d.). Petrolatum was first delivered to the bottom of the annular gap and the copper tube withdrawn from the lysimeter as the level of petrolatum rose within the gap, until the annular

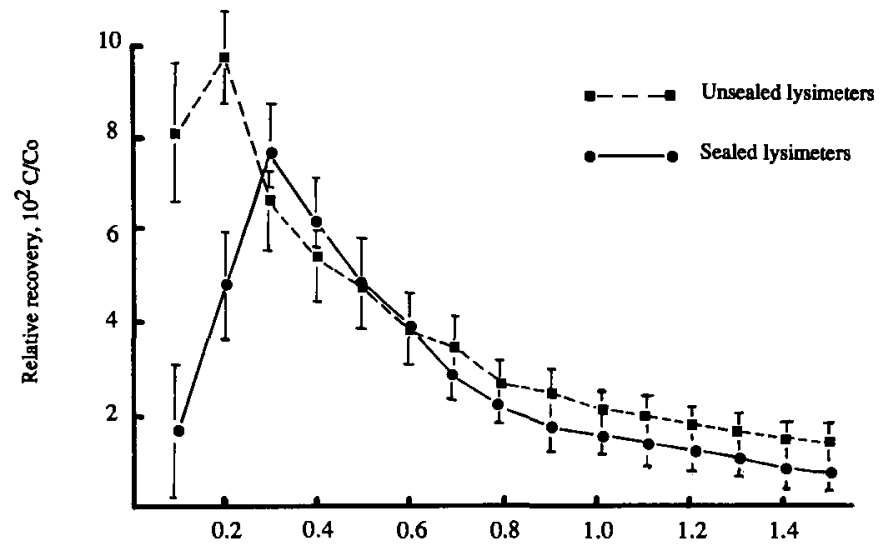

Cumulative drainage (pore volumes)

Fig. 4. Solute-leaching rates in sealed and unsealed lysimeters. Each point represents a mean of 10 replicate lysimeters. Bars represent standard errors. (Adapted from Cameron et al., 1990.) 
gap was completely filled up to the soil surface. The liquefied petrolatum was observed to flow freely from one delivery point to completely surround the side of the soil monolith. The petrolatum cooled on contact with the soil and lysimeter casing, producing a thin film of solidified petrolatum on both surfaces. When the remainder of the petrolatum in the annular gap cooled, a solid water-tight seal was produced between the soil monolith and the lysimeter casing.

The drainage outlets were attached to sealed $20-\mathrm{L}$ collection vessels. Each vessel was attached through a separate inlet port to a vacuum line, which enabled a controlled amount of suction to be transmitted to the lysimeter base. The suction applied was equivalent to the field soil matric potential measured at field capacity at an 1100-mm depth. Collection vessels were emptied manually once $15 \mathrm{~L}$ (approximately equivalent to 0.05 pore volumes of drainage) had accumulated (Fig. 2D). Subsamples of the leachate were taken for chemical analyses.

Upon completion of the experiment, soil samples were collected from the lysimeters. To do this each lysimeter was gently inverted, as described above, and the drainage systems were carefully removed. A new circular steel base plate (780-mm-diam. by $5 \mathrm{~mm}$ deep) was then placed inside the lysimeter casing. The lysimeter was reinverted and lifted until a steel support frame ( 530 by 530 by $1000 \mathrm{~mm}$ ) could be placed underneath. A chain hoist was used to gently lower the lysimeter casing to expose a portion of the soil monolith. The presence of the petrolatum around the edge of the monolith enhanced the ease with which this procedure was carried out.

\section{Results}

Visual examination of a prototype lysimeter confirmed that the petrolatum had completely encased the monolith and that it had not penetrated any significant distance into the soil. Preliminary tests also showed that plant roots did not enter the petrolatum. Petrolatum is a suitable sealant for water-flux and nutrient-leaching studies, but is unsuitable for pesticide studies due to the lipid-soluble properties of most pesticides.

Preliminary research work using smaller lysimeters ( $200 \mathrm{~mm}$ diam. by $250 \mathrm{~mm}$ ) containing the Templeton silt loam soil demonstrated that large differences in water and solute flow can occur if a conventional lysimeter design is used and the edge of the monolith is not sealed (Cameron et al., 1990). In these preliminary studies, soil hydraulic conductivity was measured by recording the time interval required to collect a standard volume of drainage ( 0.1 pore volume) under a 2-cm constant head of water. Solute breakthrough curves were obtained from a pulse application of solute leached under saturated-flow conditions (for details, see Cameron et al., 1990). Hydraulic-conductivity rates were found to be two times higher in conventional unsealed lysimeters than in sealed lysimeters using the new design (Fig. 3). Solute-leaching rates were also reported to be faster, with the more rapid emergence of surface-applied tracers in the leachate emerging from the conventional, unsealed lysimeters (Fig. 4).

As the full length of the soil monolith was sealed with petrolatum, any accidental undercutting of the side of the monlith during sampling was of no consequence. Similarly, any voids created by the removal of stones from below the cutting edge were filled with petrolatum and could therefore not influence soil water flow. Both of these problems are difficult to overcome with the conventional straight-wall lysimeter design.

The lysimeters are currently being used to measure the leaching losses of ${ }^{15} \mathrm{~N}$ and ${ }^{35} \mathrm{~S}$ from animal urine returns on pasture soils.

\section{Conclusions}

A modified lysimeter design and sampling procedure was used to collect undisturbed soil cores in which edge flow of water and solutes was reduced. One of the major long-standing criticisms of lysimeter results, arising from the uncertainty of edge flow between the soil monolith and lysimeter casing, can now be avoided. The petrolatum sealant that was used is suitable for studying leaching of inorganic substances but unfortunately cannot be used in pesticide studies.

\section{References}

Barraclough, D., E.L. Geens, and J.M. Maggs. 1984. Fate of fertiliser nitrogen applied to grassland: V. Nitrogen-15 leaching results. J. Soil Sci. 35:191-199.

Belford, R.K. 1979. Collection and evaluation of large soil monoliths for soil and crop studies. J. Soil Sci. 30:363-373.

Brown, K.W., J.C. Thomas, and M.W. Aurelius. 1985. Collecting and testing barrel sized undisturbed soil monoliths. Soil Sci. Soc. Am. J. 49:1067-1069.

Cameron, K.C., D.F. Harrison, N.P. Smith, and C.D.A. McLay. 1990. A method to prevent edge-flow in undisturbed soil cores and lysimeters. Aust. J. Soil Res. 28:879-886.

Cassell, D.K., T.H. Krueger, F.W. Schroer, and E.B. Norum 1974. Solute movement through disturbed and undisturbed soil cores. Soil Sci. Soc. Am. Proc. 38:36-40.

Chichester, F.W., and S.J. Smith. 1978. Disposition of ${ }^{15} \mathrm{~N}$-labelled fertilizer nitrate applied during corn culture in field lysimeters. J. Environ. Qual. 7:227-233.

Dowdell, R.J., and C.P. Webster. 1980. A lysimeter study using nitrogen-15 on the uptake of fertiliser nitrogen by perennial rye grass swards and losses by leaching. J. Soil Sci. 31:65-75.

Harrold, L.L., and F.R. Dreibelbis. 1958. Evaluation of agricultural hydrology by monolith lysimeters 1944-55. USDA Tech Bull. 1179. U.S. Gov. Print. Office, Washington, DC.

Harrold, L.L., and F.R. Dreibelbis. 1967. Evaluation of agricultural hydrology by monolith lysimeters 1956-62. USDA Tech. Bull. 1367. U.S. Gov. Print. Office, Washington, DC.

Howell, T.A., A.D. Schneider, and M.E. Jensen. 1991. History of lysimeter design and use for evapotranspiration measurements p. 1-10. In R.G. Allen et al. (ed.) Lysimeters for evapotranspiration and environmental measurements. Am. Soc. Civ. Eng., New York.

Kear B.S., H.S. Gibbs, R.B. Miller. 1967. Soils of the downs and plains, Canterbury and North Otago, New Zealand. Bull. no. 14. New Zealand Bureau, Wellington.

Miller, N.H.J. 1906. The amount and composition of the drainage through unmanured and uncropped land, Barnfield, Rothamsted. J. Agric. Sci. (Cambridge) 1:377-399.

Morgan, M.F., J.G.M. Jacobson, and D.E. Street, 1942. The neutralization of acid forming nitrogenous fertilizers in relation to nitrogen availability and soil bases. Soil Sci. 54:127-148.

Persson, L., and L. Bergstrom. 1991. Drilling method for collection of undisturbed soil monoliths. Soil Sci. Soc. Am. J. 55:285287.

Pfaff, C. 1963. Das Verhalten des Stickstoffs im Boden nach langjahrigen Lysimeterversuchen. I. Mittelung. Z. Acker Pflanzenbau 117:77-99.

Till, A.R., and T.B. McCabe. 1976. Sulphur leaching and lysimeter characterization. Soil Sci. 121:44-47.

Wild, A., and K.C. Cameron. 1980. Soil nitrogen and nitrate leaching. p. 35-70. In P.B. Tinker (ed.) Soils and agriculture. Blackwell Sci. Publ., Oxford, England. 